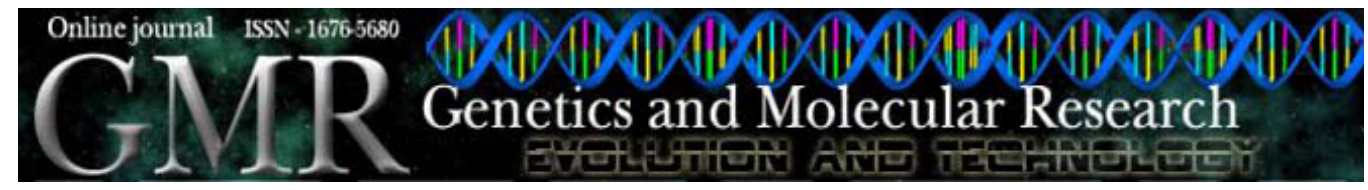

\title{
Absence of mutagenicity effects of Psidium cattleyanum Sabine (Myrtaceae) extract on peripheral blood and bone marrow cells of mice
}

\author{
T.D.A. Costa ${ }^{1}$, S. Vieira ${ }^{1}$, S.F. Andrade ${ }^{2}$ and E.L. Maistro ${ }^{1}$ \\ ${ }^{1}$ Departamento de Fonoaudiologia, Faculdade de Filosofia e Ciências, \\ Universidade Estadual Paulista, Marília, SP, Brasil \\ ${ }^{2}$ Núcleo de Investigações Químico-Farmacêuticas, \\ Universidade do Vale do Itajaí, Itajaí, SC, Brasil \\ Corresponding author: E.L. Maistro \\ E-mail: edson.maistro@marilia.unesp.br
}

Genet. Mol. Res. 7 (3): 679-686 (2008)

Received June 2, 2008

Accepted June 30, 2008

Published July 29, 2008

\begin{abstract}
Cattley guava (Psidium cattleyanum Sabine) is a native fruit of Brazil that is popular both as a sweet food and for its reputed therapeutic properties. We examined whether it could damage DNA using the alkaline single-cell gel electrophoresis (comet assay) and the micronucleus test in leukocytes and in bone marrow cells of mice. P. cattleyanum leaf extract was tested at concentrations of 1000,1500 and $2000 \mathrm{mg} / \mathrm{kg}$. N-nitroso-N-ethylurea was used as a positive control. Peripheral blood leukocytes were collected 4 and $24 \mathrm{~h}$ after the treatments for the comet assay, and bone marrow cells were collected after 24 and $48 \mathrm{~h}$ for the micronucleus test. Unlike $\mathrm{N}$-nitroso-N-ethylurea, $P$. cattleyanum extract failed to induce a significant increase in cell DNA damage, in micronucleated cell frequency, and in bone marrow toxicity. The lack of mutagenicity and cytotoxicity with high doses of this plant extract means that it can be safely used in traditional medicine.
\end{abstract}

Key words: Psidium cattleyanum; Comet assay; Micronucleus test; Single-cell gel electrophoresis; Mutagenesis 


\section{INTRODUCTION}

The species Psidium cattleyanum Sabine (Myrtaceae), a type of guava, is a sample of plant commonly used in popular medicine. It is a small bushy tree (3-6 $\mathrm{m}$ tall) with shiny smooth leathery, shiny foliage and is native to Brazil. P. cattleyanum is known in Brazil by various popular names, including "araçá-rosa, araçá-de-comer, and araçá-da-praia". The fruit is a red or yellow spherical berry with a sweet and juicy pulp that smells somewhat like strawberries. The fruits are used in jams and ice cream or are eaten raw. They contain $400 \mathrm{mg}$ of vitamin C per $100 \mathrm{~g}$ of fruit. The cultivar "Luteum" (Yellow Strawberry Guava) has yellow fruit, while the cultivar "Purpureum" (Purple Strawberry Guava) has red to purple fruit (Carvalho, 1994; Lorenzi, 1998). Plants belonging to the Psidium genus have been found to have several therapeutic properties. Pharmacological investigations indicated that $P$. guajava bark, fruit, and leaves possess antibacterial, hypoglycemic, anti-inflammatory, analgesic, antipyretic, spasmolytic, and central nervous system-depressant activities, and are used in popular medicine (Begum et al., 2002). de Souza et al. (2004) reported antimicrobial effects of the $P$. cattleyanum extract; microbicidal activity was also reported for other plants of the Psidium genus (Vieira et al., 2001, Begum et al., 2002, Sanches et al., 2005).

Medicinal plants or plants, in general, synthesize toxic substances, which in nature act as a defense against infections, insects and herbivores; however, they also can affect man (Cuzzolin et al., 2006). An assessment of their mutagenic and cytotoxic potential is necessary to ensure a relatively safe use of plant-derived medicines.

The alkaline comet and micronucleus have been the most commonly used assays for the screening of potential genotoxicants (MacGregor et al., 1987; Rojas et al., 1999; Hartmann et al., 2001) that utilize a variety of cell types. While the alkaline version of the comet assay (Singh et al., 1988) detects primary (repairable) single- and double-strand breaks and alkali-labile sites before and after DNA repair process, the micronucleus test detects DNA lesions after their fixation as chromosome mutations. We used the comet and micronucleus assays to determine if acute administration of $P$. cattleyanum leaf extract has genotoxic/mutagenic effects.

\section{MATERIAL AND METHODS}

\section{Plant material}

P. catlleyanum leaves were collected from the Campus of the "Universidade do Oeste de Santa Catarina - UNOESC", Videira, Santa Catarina State, Brazil, in September 2006. The material was identified by Dr. Sérgio Faloni de Andrade. A voucher specimen was deposited at the Herbarium of UNOESC, Videira, under accession number S.F. 015. The leaves of $P$. catlleyanum were dried with warm air $\left(40^{\circ} \mathrm{C}\right)$. The dried leaves $(400 \mathrm{~g})$ were ground in a knife mill, and soaked in with $70 \%$ aqueous ethanol $(\mathrm{v} / \mathrm{v})$ at room temperature for 7 days. The macerated leaves were filtered and resulting extract concentrated under reduced pressure, yielding $51.0 \mathrm{~g}(12.75 \%)$ of crude hydroalcoholic extract.

\section{Chemicals}

N-nitroso-N-ethylurea (ENU, CAS No. 759-73-9) was used as the DNA-damaging agent in the comet and micronucleus assays. It was dissolved in phosphate buffer, $\mathrm{pH}$ 
6. The other main chemicals were obtained from the following suppliers: normal melting point agarose (cat. No. 15510-019, Invitrogen); low melting point agarose (cat. No. 15517-014, Invitrogen); sodium salt $N$-lauroyl sarcosine (L-5125, Sigma) and ethylenediaminetetraacetic acid (EDTA; Merck).

\section{Animals and dosing}

Experiments were carried out in 12-week-old male Swiss albine mice (Mus musculus), weighing 25-30 g. The animals were acquired from the animal house of the Universidade Estadual Paulista (UNESP), Botucatu, São Paulo State, Brazil, kept in polyethylene boxes $(\mathrm{N}=11)$, in a climate-controlled environment $\left(25 \pm 4^{\circ} \mathrm{C}, 55 \pm 5 \%\right.$ humidity $)$ with a 12-h light/dark cycle (7:00 am to 7:00 pm). Food (Nuvilab CR1 - Nuvital) and water were available ad libitum. The mice were divided into 5 experimental groups of 11 animals each. $P$. cattleyanum leaf extract was administered in a single dose of $0.5 \mathrm{~mL}$ by gavage, at concentrations of 1000,1500 , and $2000 \mathrm{mg} / \mathrm{kg}$ body weight, chosen on the basis of our acute toxicity studies in mice, which was higher than $2000 \mathrm{mg} / \mathrm{kg}$. The negative control group received distilled water and the positive control group received an intraperitoneal injection of ENU at $50 \mathrm{mg} / \mathrm{kg}$. The animals used in this study were sacrificed by cervical dislocation. The Animal Bioethical Committee of the UNESP, Botucatu, Brazil, approved the present study on September 28, 2006 (protocol No. 47/06), in accordance with the federal government legislation on animal care.

\section{Comet assay}

The comet assay (single-cell gel electrophoresis, SCGE) was carried out using the method described by Speit and Hartmann (1999), which is based on the original study of Singh et al. (1988) and includes modifications introduced by Klaude et al. (1996), with additional modifications. Four and $24 \mathrm{~h}$ after the treatment, peripheral blood leukocytes from 6 Swiss mice from each group were sampled. A $10-\mu \mathrm{L}$ aliquot of cells from each animal was mixed with $120 \mu \mathrm{L} 0.5 \%$ low melting point agarose at $37^{\circ} \mathrm{C}$, and rapidly spread onto microscope slides pre-coated with $1.5 \%$ normal melting point agarose. Coverslips were added and the slides were allowed to gel at $4^{\circ} \mathrm{C}$ for $20 \mathrm{~min}$. The coverslips were gently removed and the slides were then immersed in cold, freshly prepared lysing solution consisting of $89 \mathrm{~mL}$ of a stock solution $(2.5 \mathrm{M} \mathrm{NaCl}, 100 \mathrm{mM}$ EDTA, $10 \mathrm{mM}$ Tris, pH set to 10.0 , with $\sim 8 \mathrm{~g}$ solid $\mathrm{NaOH}, 890 \mathrm{~mL}$ distilled water and $1 \%$ sodium lauryl sarcosine), plus $1 \mathrm{~mL}$ Triton X-100 (Merck) and $10 \mathrm{~mL}$ dimethylsulfoxide (Merck). The slides were protected from light and kept to stand at $4^{\circ} \mathrm{C}$ for $1 \mathrm{~h}$ and then placed in the gel box, positioned at the anode end, and immersed in a high $\mathrm{pH}(>13)$ electrophoresis buffer $(300$ $\mathrm{mM} \mathrm{NaOH}$ per $1 \mathrm{mM}$ EDTA, prepared from a stock solution of $10 \mathrm{~N} \mathrm{NaOH}$ and $200 \mathrm{mM}$ EDTA, $\mathrm{pH} 10.0$ ) at $4^{\circ} \mathrm{C}$ for $20 \mathrm{~min}$ prior to electrophoresis, to allow the DNA to unwind. The electrophoresis run was carried out in an ice bath $\left(4^{\circ} \mathrm{C}\right)$ for $20 \mathrm{~min}$ at $300 \mathrm{~mA}$ and $25 \mathrm{~V}\left(0.722 \mathrm{~V} \mathrm{~cm}^{-1}\right)$. The slides were then submerged in a neutralization buffer $(0.4 \mathrm{M}$ Tris- $\mathrm{HCl}, \mathrm{pH} 7.5$ ) for $15 \mathrm{~min}$, dried at room temperature and fixed in $100 \%$ ethyl alcohol for $10 \mathrm{~min}$. The slides were dried and stored overnight or longer, before staining. For the staining process, the slides were briefly rinsed in distilled water, covered with $30 \mu \mathrm{L} 1 \mathrm{X}$ 
ethidium bromide-staining solution prepared from a 10X stock $(200 \mu \mathrm{g} / \mathrm{mL})$ and covered with a coverslip. The material was evaluated immediately at a $400 \mathrm{X}$ magnification, using a fluorescence microscope (Olympus BX 50) with a 515-560-nm excitation filter and a 590 -nm barrier filter.

\section{Micronucleus assay}

The micronucleus assay was carried out following standard protocols, as recommended by Schmid (1975) and Krishna and Hayashi (2000). Ten mice were used per group (five for each gender) in the test. Five animals of each group were sacrificed $24 \mathrm{~h}$ after the treatment and the others five, $48 \mathrm{~h}$ later. The bone marrow from both femurs was flushed out using $2 \mathrm{~mL} 0.9 \% \mathrm{NaCl}$ and centrifuged for $7 \mathrm{~min}$. The supernatant was discarded and spread smears made. The slides were coded for a "blind" analysis, fixed with methanol and stained by Giemsa solution. For the analysis of the micronucleated cells, 2000 polychromatic erythrocytes (PCE) per animal were scored to determine the mutagenic property of the extract. To detect possible cytotoxic effects, the PCE:NCE (normochromatic erythrocytes) ratio in 200 erythrocytes/animal was calculated (Gollapudi and McFadden, 1995). Coded slides were scored with a light microscope at a 1000X magnification. The mean number of micronucleated PCE in individual mice was used as the experimental unit, with variability (standard deviation) based on differences among animals within the same group.

\section{Statistical analysis}

After checking if the data from micronucleus and SCGE assays were normally distributed, they were submitted to one-way analysis of variance (ANOVA) and the Tukey-Kramer multiple comparison test (Sokal and Rohlf, 1995), using the GraphPad Instat ${ }^{\circledR}$ software, version 3.01. The results were considered to be statistically significant at $\mathrm{P}<0.05$.

\section{RESULTS AND DISCUSSION}

Specific dietary habits have been associated with cancer of the stomach, colon, prostate, and breast. In recent years, increased attention has focused on whether naturally occurring compounds present in some foods can produce genotoxic, mutagenic or carcinogenic effects (Ferguson, 2001). Since the use of $P$. cattleyanum is becoming popular and its extract had never been analyzed for genotoxic/mutagenic properties, in the present study, we tested three concentrations of this extract in vivo. P. cattleyanum was administered by gavage since this is the most common route of human exposure to this extract. According to Preston et al. (1987), it is probably most appropriate for predicting effects in humans to utilize a route of exposure that most resembles that anticipated or known to be the route of human exposure. Furthermore, the gastrointestinal tract is one of the most important sites where chemicals are absorbed (Klaassen and Rozman, 1991).

The results of the $P$. cattleyanum extract by the comet assay, namely data on the total number of cells with damage, and scores of mice dosed with 1000, 1500, and 2000 
$\mathrm{mg} / \mathrm{kg}$, besides negative and positive control $(50 \mathrm{mg}$ ENU/ $\mathrm{kg}$ ) are presented in Tables 1 and 2. As expected, ENU, the positive control, induced a significant increase in DNA migration in leukocytes $(\mathrm{P}<0.001)$. Although there was some increase in damaged cells in the animals of the group treated with high doses of the extract, no significant differences were found between treated $v s$ untreated animals $(\mathrm{P}>0.05)$. When cells were exposed to three concentrations of the extract, most of the cells examined on slides were undamaged, a few cells showed minor damage (class 1 ) and very few had a large amount of damage (classes 2 and 3). There were also no significant differences in DNA migration between the three extract concentrations tested and between the two leukocyte time samples $(4 \mathrm{~h}$, before the DNA cell repair process, and $24 \mathrm{~h}$, after the DNA repair process).

Table 1. DNA migration in the comet assay for the assessment of genotoxicity of Psidium cattleyanum extract in peripheral blood cells collected from male Swiss mice $4 \mathrm{~h}$ after the treatment.

\begin{tabular}{|c|c|c|c|c|c|c|c|}
\hline \multirow[t]{2}{*}{ Treatments } & \multirow[t]{2}{*}{ Animals } & \multirow[t]{2}{*}{ Total $^{1}$} & \multicolumn{4}{|c|}{ Comet class } & \multirow[t]{2}{*}{ Scores } \\
\hline & & & 0 & 1 & 2 & 3 & \\
\hline Control & $\begin{array}{c}\mathrm{M}_{1} \\
\mathrm{M}_{2} \\
\mathrm{M}_{3} \\
\mathrm{M}_{4} \\
\mathrm{M}_{5} \\
\mathrm{M}_{6} \\
\text { Mean } \pm \mathrm{SD}\end{array}$ & $\begin{array}{c}3 \\
2 \\
1 \\
2 \\
3 \\
3 \\
2.33 \pm 0.81\end{array}$ & $\begin{array}{l}97 \\
98 \\
99 \\
98 \\
97 \\
97\end{array}$ & $\begin{array}{l}3 \\
2 \\
1 \\
2 \\
3 \\
3\end{array}$ & $\begin{array}{l}0 \\
0 \\
0 \\
0 \\
0 \\
0\end{array}$ & $\begin{array}{l}0 \\
0 \\
0 \\
0 \\
0 \\
0\end{array}$ & $\begin{array}{c}3 \\
2 \\
1 \\
2 \\
3 \\
3 \\
2.33 \pm 0.81\end{array}$ \\
\hline $\begin{array}{l}\text { P. cattleyanum extract } \\
(1000 \mathrm{mg} / \mathrm{kg})\end{array}$ & $\begin{array}{c}\mathrm{M}_{1} \\
\mathrm{M}_{2} \\
\mathrm{M}_{3} \\
\mathrm{M}_{6} \\
\mathrm{M}_{7} \\
\mathrm{M}_{8} \\
\text { Mean } \pm \mathrm{SD}\end{array}$ & $\begin{aligned} 2 \\
3 \\
1 \\
1 \\
1 \\
1 \\
1.50 \pm 0.83\end{aligned}$ & $\begin{array}{l}98 \\
97 \\
99 \\
99 \\
99 \\
99\end{array}$ & $\begin{array}{l}2 \\
3 \\
1 \\
1 \\
1 \\
1\end{array}$ & $\begin{array}{l}0 \\
0 \\
0 \\
0 \\
0 \\
0\end{array}$ & $\begin{array}{l}0 \\
0 \\
0 \\
0 \\
0 \\
0\end{array}$ & $\begin{aligned} 2 \\
3 \\
1 \\
1 \\
1 \\
1 \\
1.50 \pm 0.83\end{aligned}$ \\
\hline $\begin{array}{l}\text { P. cattleyanum extract } \\
(1500 \mathrm{mg} / \mathrm{kg})\end{array}$ & $\begin{array}{c}\mathrm{M}_{1} \\
\mathrm{M}_{2} \\
\mathrm{M}_{3} \\
\mathrm{M}_{6} \\
\mathrm{M}_{7} \\
\mathrm{M}_{8} \\
\text { Mean } \pm \mathrm{SD}\end{array}$ & $\begin{array}{c}10 \\
12 \\
4 \\
7 \\
5 \\
4 \\
7.00 \pm 3.34\end{array}$ & $\begin{array}{l}90 \\
88 \\
96 \\
93 \\
95 \\
96\end{array}$ & $\begin{array}{r}10 \\
12 \\
4 \\
7 \\
5 \\
4\end{array}$ & $\begin{array}{l}0 \\
0 \\
0 \\
0 \\
0 \\
0\end{array}$ & $\begin{array}{l}0 \\
0 \\
0 \\
0 \\
0 \\
0\end{array}$ & $\begin{array}{c}10 \\
12 \\
4 \\
7 \\
5 \\
4 \\
7.00 \pm 3.34\end{array}$ \\
\hline $\begin{array}{l}\text { P. cattleyanum extract } \\
(2000 \mathrm{mg} / \mathrm{kg})\end{array}$ & $\begin{array}{c}\mathrm{M}_{1} \\
\mathrm{M}_{2} \\
\mathrm{M}_{3} \\
\mathrm{M}_{7} \\
\mathrm{M}_{8} \\
\mathrm{M}_{1^{*}} \\
\mathrm{Mean} \pm \mathrm{SD}\end{array}$ & $\begin{array}{c}10 \\
2 \\
6 \\
5 \\
6 \\
7 \\
6.00 \pm 2.60\end{array}$ & $\begin{array}{l}90 \\
98 \\
94 \\
95 \\
94 \\
93\end{array}$ & $\begin{array}{r}10 \\
2 \\
6 \\
5 \\
6 \\
7\end{array}$ & $\begin{array}{l}0 \\
0 \\
0 \\
0 \\
0 \\
0\end{array}$ & $\begin{array}{l}0 \\
0 \\
0 \\
0 \\
0 \\
0\end{array}$ & $\begin{array}{c}10 \\
2 \\
6 \\
5 \\
6 \\
7 \\
6.00 \pm 2.60\end{array}$ \\
\hline $\begin{array}{l}\text { N-nitroso-N-ethylurea } \\
(50 \mathrm{mg} / \mathrm{kg})\end{array}$ & $\begin{array}{c}\mathrm{M}_{1} \\
\mathrm{M}_{2} \\
\mathrm{M}_{3} \\
\mathrm{M}_{4} \\
\mathrm{M}_{5} \\
\mathrm{M}_{6} \\
\text { Mean } \pm \mathrm{SD}\end{array}$ & $\begin{array}{c}52 \\
40 \\
49 \\
31 \\
39 \\
49 \\
43.3 \pm 8.01^{*}\end{array}$ & $\begin{array}{l}48 \\
60 \\
51 \\
69 \\
61 \\
51\end{array}$ & $\begin{array}{l}51 \\
40 \\
48 \\
31 \\
39 \\
49\end{array}$ & $\begin{array}{l}1 \\
0 \\
1 \\
0 \\
0 \\
0\end{array}$ & $\begin{array}{l}0 \\
0 \\
0 \\
0 \\
0 \\
0\end{array}$ & $\begin{array}{c}53 \\
40 \\
50 \\
31 \\
39 \\
49 \\
43.6 \pm 8.38^{*}\end{array}$ \\
\hline
\end{tabular}

${ }^{*}$ Significantly different from the negative control $(\mathrm{P}<0.001) .{ }^{1}$ Total number of damaged cells $($ classes $1+2+3)$. 
Table 2. DNA migration in the comet assay for the assessment of genotoxicity of Psidium cattleyanum extract in peripheral blood cells collected from male Swiss mice $24 \mathrm{~h}$ after the treatment.

\begin{tabular}{|c|c|c|c|c|c|c|c|}
\hline \multirow[t]{2}{*}{ Treatments } & \multirow[t]{2}{*}{ Animals } & \multirow[t]{2}{*}{ Total } & \multicolumn{4}{|c|}{ Comet class } & \multirow[t]{2}{*}{ Scores } \\
\hline & & & 0 & 1 & 2 & 3 & \\
\hline \multirow[t]{7}{*}{ Control } & $\mathrm{M}_{1}$ & 2 & 98 & 2 & 0 & 0 & 2 \\
\hline & $\mathrm{M}_{2}$ & 1 & 99 & 1 & 0 & 0 & 1 \\
\hline & $\mathrm{M}_{3}$ & 3 & 97 & 3 & 0 & 0 & 3 \\
\hline & $\mathrm{M}_{4}$ & 4 & 96 & 4 & 0 & 0 & 4 \\
\hline & $\mathrm{M}_{5}$ & 3 & 97 & 3 & 0 & 0 & 3 \\
\hline & $\mathrm{M}_{6}$ & 2 & 98 & 2 & 0 & 0 & 2 \\
\hline & Mean \pm SD & $2.50 \pm 1.04$ & & & & & $2.50 \pm 1.04$ \\
\hline \multirow{7}{*}{$\begin{array}{l}\text { P. cattleyanum extract } \\
(1000 \mathrm{mg} / \mathrm{kg})\end{array}$} & $\mathrm{M}_{1}$ & 0 & 100 & 0 & 0 & 0 & 0 \\
\hline & $\mathrm{M}_{2}$ & 1 & 99 & 1 & 0 & 0 & 1 \\
\hline & $\mathrm{M}_{3}$ & 0 & 100 & 0 & 0 & 0 & 0 \\
\hline & $\mathrm{M}_{4}$ & 2 & 98 & 2 & 0 & 0 & 2 \\
\hline & $\mathrm{M}_{5}$ & 1 & 99 & 1 & 0 & 0 & 1 \\
\hline & $\mathrm{M}_{6}$ & 0 & 100 & 0 & 0 & 0 & 0 \\
\hline & Mean \pm SD & $0.66 \pm 0.81$ & & & & & $0.66 \pm 0.81$ \\
\hline \multirow{7}{*}{$\begin{array}{l}\text { P. cattleyanum extract } \\
(15000 \mathrm{mg} / \mathrm{kg})\end{array}$} & $\mathrm{M}_{1}$ & 3 & 97 & 3 & 0 & 0 & 3 \\
\hline & $\mathrm{M}_{2}$ & 8 & 92 & 8 & 0 & 0 & 8 \\
\hline & $\mathrm{M}_{3}$ & 5 & 95 & 5 & 0 & 0 & 5 \\
\hline & $\mathrm{M}_{4}$ & 9 & 91 & 9 & 0 & 0 & 9 \\
\hline & $\mathrm{M}_{5}$ & 3 & 97 & 3 & 0 & 0 & 3 \\
\hline & $\mathrm{M}_{6}$ & 5 & 95 & 5 & 0 & 0 & 5 \\
\hline & Mean \pm SD & $5.50 \pm 2.51$ & & & & & $5.50 \pm 2.51$ \\
\hline \multirow{7}{*}{$\begin{array}{l}\text { P. cattleyanum extract } \\
(2000 \mathrm{mg} / \mathrm{kg})\end{array}$} & $\mathrm{M}_{1}$ & 6 & 94 & 6 & 0 & 0 & 6 \\
\hline & $\mathrm{M}_{2}$ & 6 & 94 & 6 & 0 & 0 & 6 \\
\hline & $\mathrm{M}_{3}$ & 1 & 99 & 1 & 0 & 0 & 1 \\
\hline & $\mathrm{M}_{4}$ & 8 & 92 & 8 & 0 & 0 & 8 \\
\hline & $\mathrm{M}_{5}$ & 7 & 93 & 7 & 0 & 0 & 7 \\
\hline & $\mathrm{M}_{6}$ & 1 & 99 & 1 & 0 & 0 & 1 \\
\hline & Mean \pm SD & $4.83 \pm 3.06$ & & & & & $4.83 \pm 3.06$ \\
\hline \multirow{7}{*}{$\begin{array}{l}\text { N-nitroso-N-ethylurea } \\
(50 \mathrm{mg} / \mathrm{kg})\end{array}$} & $\mathrm{M}_{1}$ & 45 & 55 & 43 & 2 & 0 & 47 \\
\hline & $\mathrm{M}_{2}$ & 42 & 58 & 42 & 0 & 0 & 42 \\
\hline & $\mathrm{M}_{3}^{2}$ & 55 & 45 & 54 & 1 & 0 & 56 \\
\hline & $\mathrm{M}_{4}$ & 40 & 60 & 40 & 0 & 0 & 40 \\
\hline & $\mathrm{M}_{5}$ & 37 & 63 & 37 & 0 & 0 & 37 \\
\hline & $\mathrm{M}_{6}$ & 62 & 38 & 62 & 0 & 0 & 62 \\
\hline & Mean \pm SD & $46.8 \pm 9.66^{*}$ & & & & & $47.3 \pm 9.79 *$ \\
\hline
\end{tabular}

*Significantly different from the negative control $(\mathrm{P}<0.001) .{ }^{1}$ Total number of damaged cells (classes $\left.1+2+3\right)$.

The micronucleus data for P. cattleyanum extract are summarized in Table 3. All results regarding micronucleated cells were not statistically different from the negative control. Also, no significant differences between the groups tested were observed. The estimated PCE:NCE ratio in bone marrow preparations showed a statistical increase in hematopoiesis as a result of extract treatment, indicating no cytotoxic effects.

Teixeira et al. (2003) evaluated the effects of the infusions of Psidium guajava in in vitro and in in vivo assays on chromosomes and the cell cycle. The two different concentrations of the infusions did not cause a statistically significant alteration in Allium cepa L. root-tip cells, in rat cells 


\begin{tabular}{|c|c|c|c|c|c|c|c|c|}
\hline \multirow[t]{2}{*}{ Treatments } & \multirow[t]{2}{*}{$\begin{array}{l}\text { Time of blood } \\
\text { collection }\end{array}$} & \multicolumn{5}{|c|}{$\begin{array}{c}\text { Number of MNPCE } \\
\text { per animal }\end{array}$} & \multirow[t]{2}{*}{$\begin{array}{c}\text { MNPCE } \\
(\text { mean } \pm \text { SD) }\end{array}$} & \multirow[t]{2}{*}{$\begin{array}{c}\mathrm{PCE} / \mathrm{NCE} \\
(\text { mean } \pm \mathrm{SD})\end{array}$} \\
\hline & & $\mathrm{M}_{1}$ & $\mathrm{M}_{2}$ & $\mathrm{M}_{3}$ & $\mathrm{M}_{4}$ & $\mathrm{M}_{5}$ & & \\
\hline \multirow{2}{*}{$\begin{array}{l}\text { Negative control } \\
\text { (water) }\end{array}$} & $24 \mathrm{~h}$ & 4 & 3 & 2 & 3 & 4 & $3.20 \pm 0.83$ & $0.86 \pm 0.17$ \\
\hline & $48 \mathrm{~h}$ & 2 & 4 & 3 & 2 & 5 & $3.20 \pm 1.30$ & $0.64 \pm 0.09$ \\
\hline \multirow{2}{*}{$\begin{array}{l}\text { P. cattleyanum extract } \\
(1000 \mathrm{mg} / \mathrm{kg})\end{array}$} & $24 \mathrm{~h}$ & 4 & 3 & 2 & 3 & 2 & $2.80 \pm 0.83$ & $0.71 \pm 0.14$ \\
\hline & $48 \mathrm{~h}$ & 2 & 2 & 2 & 3 & 2 & $2.20 \pm 0.44$ & $0.91 \pm 0.09^{\mathrm{b}}$ \\
\hline \multirow{2}{*}{$\begin{array}{l}\text { P. cattleyanum extract } \\
(1500 \mathrm{mg} / \mathrm{kg})\end{array}$} & $24 \mathrm{~h}$ & 2 & 2 & 5 & 2 & 2 & $2.60 \pm 1.34$ & $1.01 \pm 0.10^{\mathrm{b}}$ \\
\hline & $48 \mathrm{~h}$ & 2 & 1 & 1 & 1 & 1 & $1.20 \pm 0.44$ & $0.92 \pm 0.14$ \\
\hline \multirow{2}{*}{$\begin{array}{l}\text { P. cattleyanum extract } \\
(2000 \mathrm{mg} / \mathrm{kg})\end{array}$} & $24 \mathrm{~h}$ & 4 & 2 & 4 & 2 & 3 & $3.00 \pm 1.00$ & $0.98 \pm 0.05^{\mathrm{a}, \mathrm{b}}$ \\
\hline & $48 \mathrm{~h}$ & 1 & 2 & 3 & 2 & 2 & $2.00 \pm 0.70$ & $1.14 \pm 0.14^{\mathrm{b}}$ \\
\hline \multirow{2}{*}{$\begin{array}{l}\text { N-nitroso-N-ethylurea } \\
(50 \mathrm{mg} / \mathrm{kg})\end{array}$} & $24 \mathrm{~h}$ & 9 & 8 & 7 & 8 & 8 & $8.00 \pm 0.70^{\mathrm{a}, \mathrm{b}}$ & $0.81 \pm 0.09$ \\
\hline & $48 \mathrm{~h}$ & 7 & 6 & 5 & 7 & 6 & $6.20 \pm 0.83^{\mathrm{a}, \mathrm{b}}$ & $1.03 \pm 0.09^{\mathrm{b}}$ \\
\hline
\end{tabular}

Two thousand cells were analyzed per animal for each time period. SD = standard deviation; PCE = polychromatic

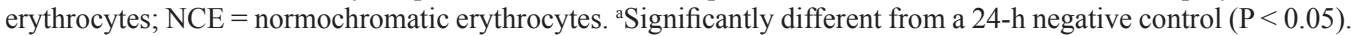
${ }^{\mathrm{b} S i g n i f i c a n t l y ~ d i f f e r e n t ~ f r o m ~ a ~ 48-h ~ n e g a t i v e ~ c o n t r o l ~}(\mathrm{P}<0.05)$.

or in cultured human lymfocytes. These are the only available mutagenicity data for Psidium plants spp. P. guajava contains essential oils, rutin, tannins, flavonoids, sesquiterpenic alcohol, and triterpenoid acids (Silva et al., 1995). We also found no mutagenic effects of $P$. cattleyanum. Despite there is no information available on P. cattleyanum leaf phytochemicals, plants belonging to the same genus generally do not diverge in the chemical structure of major components (Porto et al., 2000).

The results obtained showed that the mixed compounds present in the leaf extract have no genotoxic/mutagenic effects on some cell types in vivo of Mus musculus mice. Thus, the data obtained in the present study permit us to conclude that, under the experimental conditions employed here, the $P$. cattleyanum leaf extract appears to be safe as a therapeutic agent.

\section{ACKNOWLEDGMENTS}

We would like to thank the Brazilian agencies CNPq (\#306544/2006-7) and FAPESP - Fundação de Amparo à Pesquisa do Estado de São Paulo (\#2006/57514-2) for the financial support of this study and Patrícia C. Martins de Mello for their technical assistance.

\section{REFERENCES}

Begum S, Hassan SI, Siddiqui BS, Shaheen F, et al. (2002). Triterpenoids from the leaves of Psidium guajava. Phytochemistry 61: 399-403.

Carvalho PER (1994). Espécies florestais brasileiras - recomendações silviculturais, potencialidades e uso da madeira. EMBRAPA-CNPF/SPI, Curitiba.

Cuzzolin L, Zaffani S and Benoni G (2006). Safety implications regarding use of phytomedicines. Eur. J. Clin. Pharmacol. 62: $37-42$.

de Souza GC, Haas AP, von Poser GL, Schapoval EE, et al. (2004). Ethnopharmacological studies of antimicrobial remedies in the south of Brazil. J. Ethnopharmacol. 90: 135-143.

Ferguson LR (2001). Role of plant polyphenols in genomic stability. Mutat. Res. 475: 89-111.

Gollapudi BB and McFadden LG (1995). Sample size for the estimation of polychromatic to normochromatic erythrocyte ratio in the bone marrow micronucleus test. Mutat. Res. 347: 97-99. 
Hartmann A, Elhajouji A, Kiskinis E, Poetter F, et al. (2001). Use of the alkaline comet assay for industrial genotoxicity screening: comparative investigation with the micronucleus test. Food Chem. Toxicol. 39: 843-858.

Klaassen CD and Rozman K (1991). Absorption, Distribution, and Excretion of Toxicants. In: Toxicology: the basic science of poisons (Amdur MO, Doull J and Klaassen CD, eds.). Pergamon Press, New York, 50-87.

Klaude M, Eriksson S, Nygren J and Ahnstrom G (1996). The comet assay: mechanisms and technical considerations. Mutat. Res. 363: 89-96.

Krishna G and Hayashi M (2000). In vivo rodent micronucleus assay: protocol, conduct and data interpretation. Mutat. Res. 455: 155-166.

Lorenzi H (1998). Árvores Brasileiras: Manual de Identificação e Cultivo de Plantas Arbóreas Nativas do Brasil. Ed. Plantarum, Nova Odessa.

MacGregor JT, Heddle JA, Hite M, Margolin BH, et al. (1987). Guidelines for the conduct of micronucleus assays in mammalian bone marrow erythrocytes. Mutat. Res. 189: 103-112.

Porto AL, Machado SM, de Oliveira CM, Bittrich V, et al. (2000). Polyisoprenylated benzophenones from Clusia floral resins. Phytochemistry 55: 755-768.

Preston RJ, Dean BJ, Galloway S, Holden H, et al. (1987). Mammalian in vivo cytogenetic assays. Analysis of chromosome aberrations in bone marrow cells. Mutat. Res. 189: 157-165.

Rojas E, Lopez MC and Valverde M (1999). Single cell gel electrophoresis assay: methodology and applications. $J$. Chromatogr. B. Biomed. Sci. Appl. 722: 225-254.

Sanches NR, Cortez DAG, Schiavini MS, Nakamura CV, et al. (2005). An evaluation of antibacterial activities of Psidium guajava (L.). Braz. Arch. Biol. Technol. 48: 429-436.

Schmid W (1975). The micronucleus test. Mutat. Res. 31: 9-15.

Silva I, Franco SL, Molinari SL, Conegero CI, et al. (1995). Noções sobre o organismo humano e a utilização de plantas medicinais. Assoeste - Editora Educativa, Cascavel.

Singh NP, McCoy MT, Tice RR and Schneider EL (1988). A simple technique for quantitation of low levels of DNA damage in individual cells. Exp. Cell Res. 175: 184-191.

Sokal RR and Rohlf FJ (1995). Biometry. W.H. Freeman and Company, San Francisco, 175-205, 404-486.

Speit G and Hartmann A (1999). The comet assay (single-cell gel test). In: Methods in Molecular Biology. DNA Repair Protocols: Eukaryotic Systems (Henderson DS, ed.). Humana Press Inc., Totowa, 203-212.

Teixeira RO, Camparoto ML, Mantovani MS and Vicentini VEP (2003). Assessment of two medicinal plants, Psidium guajava L. and Achillea millefolium L. in in vivo assays. Genet. Mol. Biol. 26: 551-555.

Vieira RH, Rodrigues DP, Goncalves FA, Menezes FG, et al. (2001). Microbicidal effect of medicinal plant extracts (Psidium guajava Linn. and Carica papaya Linn.) upon bacteria isolated from fish muscle and known to induce diarrhea in children. Rev. Inst. Med. Trop. São Paulo 43: 145-148. 